\title{
JEKK
}

Jurnal Epidemiologi Kesehatan Komunitas

4 (1), 2019, 1-10

\section{Faktor-Faktor yang Berpengaruh terhadap Kejadian Demam Berdarah Dengue pada Anak Usia 6-12 Tahun Di Kecamatan Tembalang}

\author{
Tuti Sandra*, Muchlis AU Sofro ${ }^{* *}$, Suhartono ${ }^{* * *}$, Martini $^{* * *}$, Suharyo Hadisaputro*** \\ "Dinas Kesehatan Penajam Paser Utara, ${ }^{* *}$ Fakultas Kedokteran Universitas Diponegoro, ${ }^{* * *}$ Fakultas \\ Kesehatan Masyarakat Universitas Diponegoro
}

\begin{abstract}
Background : The Dengue Fever is an infectious disease that still becomes a serious health issue since it is endemic. This research aims to explain the various factors influencing the occurrences of the dengue fever in the children age 6 to 12 years old.

Methods : This research used both quantitative and qualitative methods. The quantitative research specification was the observational analytic case control design while the indept interview technique was used as the qualitative research method. The population of the study were all children age 6 to 12 years old who lived in the Semarang City. The number of the subjects were 70 cases and 70 controls and they were taken by consecutive sampling method. The data were analyzed using the bivariate and multivariate with the regression logistic method.

Results : The factors proven to influence the dengue fever occurrences in the children 6 to 12 years old were the lack of the mother's education (OR 3.031; 95\%CI 1.4281-6.434; $p=$ 0.004;), the habit of not using the insect repellent use (OR 4.293; 95\%CI 1.935-9.526; $p=$ 0.001 ) and the habit of not wearing long clothes (OR 2.759; 95\%CI 1.240-6.138; $p=0.013$ ). Conclusion : The factors recognized as the significant risk factors for the occurrences of the dengue fever in the children age 6 to 12 years old were the lack of the mother's education, the habit of not using the insect repellent and the habit of not wearing long clothes. Those factors contribute $85,3 \%$ to the occurrence of dengue fever.
\end{abstract}

Keywords: Risk factors; dengue fever; the children

Penulis korespondensi : tutisandraspian@yahoo.com 


\section{Pendahuluan}

Demam Berdarah Dengue (DBD) adalah penyakit yang disebabkan oleh virus dari keluarga flaviviridae yang ditularkan melalui gigitan nyamuk (arthropod borne viruses/arbovirus) yaitu Aedes aegypti dan Aedes albopictus dengan manifestasi klinis demam, nyeri otot/sendi disertai leukopenia, ruam, limfodenopati, trombositopenia. ${ }^{1}$ Data dari World Health Organization (WHO) tahun 2015 menyatakan 3,9 milyar penduduk dunia dinegara tropis dan subtropis terdapat 128 negara berisiko terinfeksi virus dengue dengan 96 juta kasus. ${ }^{2}$ Lebih dari 136.000 kasus DBD di Thailand dilaporkan pada bulan Agustus 2016 merupkan jumlah kasus tertinggi selama lebih dari 20 tahun. $^{2}$ DBD merupakan masalah besar di Asia Tenggara, karena selama periode 40 tahun terjadi kematian 67.295 dari total kematian di seluruh dunia sebanyak 68.977. Hal ini menunjukkan bahwa terjadi kematian rata-rata 1682/tahun karena DBD. ${ }^{1,3}$

Angka kejadian kasus DBD di Indonesia dari tahun ke tahun cenderung fluktuatif. Selama 47 tahun terakhir sejak tahun 1968 terjadi peningkatan yaitu 58 kasus menjadi 126.675 kasus pada tahun 2015 dari 436 (85\%) kabupaten/kota di Indonesia. Dalam satu dekade dari tahun 1996-2005 terjadi kenaikan kasus mulai dari 0,4 juta kasus hingga 1,5 juta kasus. Pada tahun 2010 melonjak menjadi 2,2 juta kasus. Pada tahun 2014 jumlah kasus sebanyak $100.347 \quad(\mathrm{IR}=39,80 / 100.000$ penduduk) dan terjadi peningkatan pada tahun 2015 sebanyak 129.650 kasus (IR= $50,75 / 100.000$ penduduk) dengan angka kematian 1.071 (CFR=0,83\%) dan masih mengalami peningkatan tahun 2016 tercatat 2014.171 penderita (IR= $78,85 / 100.000$ penduduk) dengan angka kematian $1.598(\mathrm{CFR}=0,78 \%){ }^{4,5}$
Menurut data Dinkes Kota Semarang pada tahun 2013 IR DBD di Kecamatan Tembalang meningkat yaitu 218,20/100.000 penduduk dengan CFR 0,53\%. Kecamatan Tembalang masih menempati peringkat pertama IR DBD tertinggi di Kota Semarang sampai tahun 2014 dengan IR DBD 166,89/100.000 penduduk dengan CFR 1,02\%. Pada tahun 2016 IR DBD di kecamatan Tembalang yaitu 70,5/100.000 penduduk dengan CFR 2,36\% dan menurun pada tahun 2017 IR 35,47/100.000 penduduk dengan CFR 3,28\%.6,7 Pada tahun 2014 tercatat penderita DBD paling banyak dialami oleh kelompok 1-14 tahun sebanyak 1.065 penderita, untuk anak usia 6-12 tahun sebanyak 336 anak, Penderita DBD pada kelompok usia 6-12 tahun di kecamatan tembalang pada tahun 2016 tertinggi yaitu173 anak dan pada tahun 2017 dari semua kelompok usia 6-12 tahun adalah tertinggi menderita DBD yaitu sebanyak 58 anak. $^{8}$

Faktor yang berperan dalam timbulnya penyakit berdasarkan segitiga epidemiologi dipengaruhi oleh faktor manusia sebagai host dan nyamuk Aedes aegypti sebagai vektor penular DBD. Lingkungan secara signifikan mempengaruhi kesakitan bagi setiap individu termasuk sosial, ekonomi dan lebih utamanya perilaku masyarakat, meningkatnya mobilitas penduduk, kepadatan hunian, semakin baiknya sarana transportasi dan masih terdapat tempat perindukan nyamuk penular DBD., ${ }^{9,10}$

Menurut penelitian yang dilakukan oleh Puspita Sari dkk bahwa ada hubungan antara praktik PSN dengan kejadian DBD pada sekolah tingkat dasar di Kota Semarang $(p$ value $=0,005) .{ }^{11}$ Faktor perilaku pencegahan yang seharusnya secara rutin dilakukan tetapi masih kurang diperhatikan dan diabaikan meliputi kebiasaan memakai pakaian panjang, kebiasaan memakai obat anti nyamuk, 
kebiasaan menggantung pakaian di dalam rumah dan kurangnya partisipasi masyarakat dengan lingkungan juga merupakan faktor yang dapat meningkatnya kejadian penyakit DBD. selain itu faktor imunitas seseorang, strain virus yang menginfeksi, riwayat dan usia juga berpengaruh. ${ }^{10,12}$

Kegiatan pemantauan jentik atau mengamati jentik secara rutin yang dilaksanakan oleh anggota keluarga sendiri di rumah masing-masing diharapkan akan lebih meningkatkan kesadaran anggota keluarga untuk segera melakukan PSNDBD tanpa menunggu hasil pemantauan jentik oleh Jumantik. Kecamatan Tembalang merupakan wilayah endemis DBD yang menempati peringkat pertama di Semarang. Kecamatan Tembalang membawahi dua wilayah kerja puskesmas yaitu puskesmas Kedungmundu dan Puskesmas Rowosari. Pada kedua Puskesmas ini setiap tahunnya terjadi kasus DBD dengan proporsi terbesar pada kelompok anak usia 6-12 tahun. ${ }^{13,14}$

Berbagai upaya pengendalian DBD sudah di lakukan tetapi kasus kejadian penyakit masih tinggi pada kelompok usia anak 1-14 tahun sebanyak 952 dan usia lebih dari 15 tahun sebanyak 308 penderita. ${ }^{8}$ Sejauh ini masih belum jelas faktor risiko kejadian DBD pada anak usia 6-12 tahun. Oleh karena itu perlu diteliti mengenai faktor risiko apa sajakah yang berpengaruh terhadap kejadian DBD pada kelompok usia anak 6-12 tahun. Berdasarkan latar belakang tersebut, maka penulis melakukan penelitian mengenai faktor risiko yang berfokus pada kebiasaan masyarakat yang biasa dilakukan di Kecamatan Tembalang di-antaranya adalah pendidikan ibu, kebiasaan memakai obat anti nyamuk, kebiasaan menggantung pakaian, kebiasaan tidak memakai pakaian panjang, kebiasaan tidur siang, adanya forum informasi dan rutinitas pemeriksaan jentik dengan kejadian DBD di Kecamatan Tembalang.

Penelitian ini bertujuan untuk menjelaskan beberapa faktor host dan environment (pendidikan ibu, penggunaan obat anti nyamuk, kebiasaan menggantung pakaian di dalam rumah, kebiasaan memakai pakaian panjang, kebiasaan tidur siang, forum penyampaian informasi dan rutinitas pemeriksaan jentik) yang berpengaruh terhadap kejadian DBD pada anak usia 6-12 tahun.

\section{Metode}

Penelitian ini menggunakan mengkobinasikan bentuk kuantitatif dan kualitatif. Spesifikasi penelitian kuantitatif yang digunakan adalah jenis penelitian observasional analitik desain case control study. Kemudian dilakukan kajian kualitatif dengan wawancara mendalam. Populasi studi adalah semua anak usia 6-12 tahun yang tinggal di Kecamatan Tembalang. Jumlah subyek sebanyak 140 responden yang terdiri atas 70 kasus dan 70 kontrol yang memenuhi kriteria inklusi dan eksklusi.

Tehnik pengambilan sampel penelitian ini menggunakan consecutive sampling Peneliti menetapkan kriteria inklusi dan eksklusi. ${ }^{15}$ Data di analisis secara bivariat untuk mengetahui besar risiko (Odds Ratio/OR) variabel bebas terhadap kasus, meng-gunakan uji chi-square dan analisis multivariat untuk mengetahui pengaruh secara bersama-sama variabel bebas terhadap variabel terikat dan variabel bebas mana yang berpengaruh paling besar terhadap variabel terikat dengan menggunakan uji regresi logistic dengan menggunakan metode enter. Semua variabel bebas yang terpilih $(p<0,25)$ di masukkan bersama-sama ke dalam analisi regresi, yang menunjukkan nilai $p<0,05$ di pilih menjadi model. 


\section{Hasil Penelitian}

Penelitian faktor yang berpengaruh terhadap kejadian DBD pada anak usia 612 tahun dengan subyek penelitian di ambil dari data pasien Puskesmas Rowosari dan Puskesmas Kedungmundu. Data primer di dapatkan dari hasil wawancara, data sekunder dari pencatatan dan pelaporan puskesmas dan dinas Kesehatan Kota Semarang sebagai data pendukung dan pelengkap.

\section{Analisis Bivariat}

\section{Pendidikan ibu}

Tingkat pendidikan ibu adalah tingkat pendidikan formal yang ditamatkan oleh responden. Proporsi pendidikan ibu pada kategori pendidikan rendah lebih besar pada kasus 45 (64,3\%) dibandingkan dengan kelompok kontrol 29 (41,4\%). Hasil uji chi square diperoleh nilai $p$ value lebih kecil dari 0,05 yaitu 0,007 yang berarti ada pengaruh faktor pendidikan ibu terhadap kejadian DBD pada anak usia 612 tahun dengan nilai $p$ value $=0,007$; Nilai $\mathrm{OR}=2,545$ berarti tingkat pendidikan ibu rendah berisiko mengalami kejadian DBD pada anak 2,5 kali lebih besar daripada ibu yang berpendidikan tinggi dengan $95 \%$ $\mathrm{CI}=1,287-5,033$.

\section{Kebiasaan memakai obat anti nyamuk}

Metode perlindungan diri digunakan oleh individu, keluarga dan masyarakat untuk melindungi diri dari gigitan nyamuk salah satunya adalah memakai obat anti nyamuk. ${ }^{16}$ Kebiasaan tidak memakai obat anti nyamuk terbukti berpengaruh terhadap kejadian DBD pada anak. Hasil uji statistik diperoleh nilai $p$ value 0,001 yang berarti ada pengaruh kebiasaan memakai obat anti nyamuk terhadap kejadian DBD pada anak dengan $p=0,001$, OR 4,000; 95\%CI 1,889-8,468

Artinya anak yang tidak memiliki kebiasaan memakai obat anti nyamuk merupakan mempunyai kemungkinan 4 kali lebih besar untuk terkena DBD dibandingkan anak yang memiliki kebiasaan memakai obat anti nyamuk.

\section{Kebiasaan tidur siang}

Hasil analisis menunjukkan bahwa kebiasaan tidur siang tidak terbukti berpengaruh terhadap kejadian DBD pada anak, uji statistik diperoleh nilai $\mathrm{OR}=1,509$ 95\% CI=769-2,964 nilai $p=0,231$ yang berarti tidak ada pengaruh faktor kebiasaan tidur siang terhadap kejadian DBD pada anak.

\section{Kebiasaan tidak memakai pakaian panjang}

Kebiasaan tidak memakai pakaian panjang terbukti berpengaruh terhadap kejadian DBD uji statistik diperoleh nilai $p=0,020 \quad \mathrm{OR}=2,338 ; 95 \% \mathrm{CI}=1,135-4,818$ yang berarti ada pengaruh faktor kebiasaan tidak memakai pakaian panjang terhadap kejadian DBD pada anak. Nilai OR sebesar 2,338 berarti orang yang mempunyai kebiasaan tidak memakai pakaian panjang berisiko 2,3 kali lebih besar terhadap kejadian DBD dibandingkan dengan orang yang mempunyai kebiasaan memakai pakaian panjang.

\section{Kebiasaan menggantung pakaian}

Kebiasaan menggantung pakaian di dalam rumah tidak terbukti berpengaruh terhadap kejadian DBD pada anak. Hasil uji statistik diperoleh nilai $p=0,128$ yang berarti tidak ada pengaruh faktor kebiasaan menggantung pakaian terhadap kejadian DBD. 


\section{Praktik PSN}

Berdasarkan hasil analisis praktik PSN terbukti berpengaruh terhadap kejadian DBD pada anak. Hasil uji statistik diperoleh nilai $p=0,025$ yang berarti ada pegaruh faktor praktik PSN yang kurang baik terhadap kejadian DBD pada anak usia 6-12 tahun ( $p=0,025 ; \mathrm{OR}=2,471 ; 95 \%$ $\mathrm{CI}=1,108-5,978)$. Artinya bahwa responden yang kurang baik dalam praktik PSN mempunyai kemungkinan 2,5 kali untuk mengalami kejadian DBD.

\section{Forum penyampaian informasi}

Adanya forum penyampaian informasi di Kecamatan Tembalang tidak terbukti berpengaruh terhadap kejadian DBD pada anak. Hasil uji statistik dipe- roleh nilai $p=0,385$ yang berarti tidak ada pengaruh faktor forum penyampaian informasi terhadap kejadian DBD pada anak usia 6-12 tahun. ( $p=0,385$; $\mathrm{OR}=$ $0,684 ; 95 \% \mathrm{CI}=0,289-1,616)$.

\section{Rutinitas pemeriksaan jentik}

Kecamatan Tembalang sudah memiliki petugas pemantau jentik yang di koordinir oleh petugas dari kecamatan dan Puskesmas sebagai pembina wilayah. Hasil analisis rutinitas pemeriksaa jentik tidak terbukti berpengaruh terhadap kejadian DBD pada anak. Hasil uji statistik diperoleh nilai $p=0,398$ yang berarti tidak ada pengaruh faktor rutinitas pemeriksaan jentik terhadap kejadian DBD pada anak usia 6-12 tahun. $(p=0,398 ; \mathrm{OR}=0,751 ; 95 \%$ $\mathrm{CI}=0,386-1,460)$.

Tabel 1. Rangkuman hasil analisis bivariat

\begin{tabular}{|c|c|c|c|c|c|c|c|}
\hline \multirow{2}{*}{ Variabel } & \multicolumn{2}{|c|}{ Kasus } & \multicolumn{2}{|c|}{ Kontrol } & \multirow{2}{*}{$95 \% \mathrm{CI}$} & \multirow{2}{*}{ OR } & \multirow[t]{2}{*}{$\begin{array}{c}p- \\
\text { value }\end{array}$} \\
\hline & $\mathrm{n}=70$ & $\%$ & $\mathrm{n}=70$ & $\%$ & & & \\
\hline \multicolumn{8}{|l|}{ Pendidikan ibu } \\
\hline - Rendah (SD,SMP) & 44 & 60,3 & 29 & 39,7 & $1,287-5,033$ & 2,545 & 0,007 \\
\hline - Tinggi (SMA,D3,PT) & 26 & 38,8 & 41 & 61,2 & & & \\
\hline \multicolumn{8}{|c|}{$\begin{array}{l}\text { Kebiasaan memakai obat anti } \\
\text { nyamuk }\end{array}$} \\
\hline - Ya & 39 & 43,3 & 51 & 56,7 & $1,889-8,468$ & 4,000 & 0,001 \\
\hline - Tidak & 31 & 62 & 19 & 38 & & & \\
\hline \multicolumn{8}{|l|}{ Kebiasaan tidur siang } \\
\hline - Ya & 33 & 55,9 & 26 & 44,1 & $0,769-2,964$ & 1,509 & 0,231 \\
\hline - Tidak & 37 & 45,7 & 44 & 54,3 & & & \\
\hline \multicolumn{8}{|c|}{$\begin{array}{l}\text { Kebiasaan tidak memakai pakaian } \\
\text { panjang }\end{array}$} \\
\hline$-\mathrm{Ya}$ & 53 & 57 & 40 & 43 & $1,135-4,818$ & 2,338 & 0,020 \\
\hline - Tidak & 17 & 30,6 & 30 & 63,8 & & & \\
\hline \multicolumn{8}{|c|}{ Kebiasaan menggantung pakaian } \\
\hline - Ya & 39 & 55,7 & 30 & 49,3 & $0,860-3,272$ & 1,677 & 0,128 \\
\hline - Tidak & 31 & 44,3 & 40 & 50,0 & & & \\
\hline \multicolumn{8}{|l|}{ Praktik PSN } \\
\hline - Kurang Baik & 13 & 72,2 & 5 & 27,8 & $1.108-5,970$ & 2,571 & 0,025 \\
\hline - Baik & 57 & 46,7 & 65 & 53,3 & & & \\
\hline Forum penyampaian inforr & & & & & & & \\
\hline
\end{tabular}




\begin{tabular}{lccccccc}
\hline - Ya & 55 & 78,6 & 59 & 8,3 & $0,289-1,616$ & 0,684 & 0,385 \\
- Tidak & 15 & 21,4 & 11 & 15,7 & & & \\
Rutinitas pemeriksaan Jentik & & & & & & & \\
- Ya & 39 & 53,4 & 34 & 46,6 & $0,386-1,460$ & 0,751 & 0,398 \\
- Tidak & 31 & 46,3 & 36 & 53,7 & & & \\
\hline
\end{tabular}

\section{Analisis Multivariat}

Analisis multivariat dilakukan untuk mengetahui pengaruh secara bersama-sama variabel bebas terhadap variabel terikat dan variabel bebas mana yang berpengaruh paling besar terhadap variabel terikat, menggunakan uji regresi logistik dengan metode enter.

Variabel bebas yang memiliki nilai $\mathrm{p}<0,25$ pada analisis bivariat. Selanjutnya dilakukan analisis interaksi secara ber- sama-sama untuk melihat kemungkinan adanya interaksi antar variabel. Persamaan model terbaik dipertimbangkan dengan nilai signifikansi $\mathrm{p}<0,05$. Adapun hasil persamaan model akhir menunjukkan ada 4 variabel independen yang terbukti sebagai faktor yang berpengaruh terhadap kejadian DBD pada anak usia 6-12 tahun yaitu pendidikan ibu rendah, kebiasaan tidak memakai obat anti nyamuk dan kebiasaan tidak memakai pakaian panjang.

Tabel 2. Rangkuman hasil analisis regresi logistik

\begin{tabular}{clccccc}
\hline No & \multicolumn{1}{c}{ Variabel } & B & Wald & p & OR & 95\%CI \\
\hline 1 & $\begin{array}{l}\text { Pendidikanibu } \\
\text { rendah(SD,SMP) }\end{array}$ & 1,109 & 8,342 & 0,004 & 3,031 & $1,428-6,434$ \\
2 & $\begin{array}{l}\text { Kebiasaan tidak memakai } \\
\text { obat anti nyamuk }\end{array}$ & 1,457 & 12,838 & 0,001 & 4,293 & $1,935-9,526$ \\
3 & $\begin{array}{l}\text { Kebiasaan tidak memakai } \\
\text { pakaian panjang }\end{array}$ & 1,015 & 6,186 & 0,013 & 2,759 & $1,240-6,138$ \\
4 & Konstanta & $-1,821$ & 17,537 & 0,001 & 0,162 & \\
\hline
\end{tabular}

\section{Pembahasan}

\section{Pendidikan ibu rendah}

Berdasarkan analisis hasil uji binary logistic nilai $p$ value $<0,04$ berarti ada pengaruh faktor pendidikan ibu rendah terhadap kejadian DBD pada anak usia 612 tahun. Dalam penelitian ini latar belakang pendidikan ibu responden penelitian tidak sama, dimana antara pendidikan rendah sebanyak $73(52,1 \%)$ dan pendidikan tinggi sebanyak 67 $(47,9 \%)$.
Faktor pendidikan merupakan unsur yang sangat penting karena dengan pendidikan seseorang dapat menerima lebih banyak informasi, memperluas cakrawala berpikir dapat mempengaruhi pola pikir dan daya cerna seseorang terhadap informasi yang diterima. Semakin tinggi tingkat pendidikan seseorang, semakin tinggi pula informasi yang dapat diserap, sehingga dapat berpengaruh terhadap pengetahuan seseorang. Pendidikan merupakan suatu usaha untuk mengembangkan kepribadian dan kemampuan didalam maupun di luar sekolah dan berlangsung seumur hidup. ${ }^{17,18}$ 
Penelitian ini hanya mengambil catatan mengenai pendidikan formal. Karena tingkat jenjang pendidikan normal dapat dipertanggung jawabkan dan terstandar. Sedangkan pendidikan informal sangat variatif dan belum mempunyai standar yang tetap.

Kurangnya pengetahuan penduduk dalam kaitannya dengan penyakit demam berdarah dapat disebabkan oleh banyak faktor, sebagaimana telah dikemukakan salah satu di antaranya adalah rendahnya tingkat pendidikan. Di samping itu, mungkin sikap masa bodoh dan kurangnya penyuluhan yang efektif menyebabkan pengetahuan masyarakat tentang penyakit menjadi rendah. Pendidikan yang relatif rendah melatar belakangi sulitnya penduduk untuk mengetahui konsep kejadian penyakit DBD.

Penelitian ini sejalan dengan penelitian yang dilakukan oleh Ayu dengan $p$ value sebesar 0,001 bahwa terdapat pengaruh yang secara statistik signifikan antara pendidikan formal dan perilaku ibu dalam pencegahan demam berdarah dengue pada keluarga. Makin tinggi tingkat pendidikan ibu, makin baik perilaku pencegahan DBD. ${ }^{19}$

\section{Kebiasaan tidak memakai pakaian panjang}

Hasil penelitian ini menunjukkan bahwa kebiasaan memakai pakaian panjang terbukti berpengaruh dengan kejadian DBD. Hasil uji binary logistic diperoleh nilai $p=0,013$ yang berarti ada pengaruh faktor kebiasaan tidak memakai pakaian panjang terhadap kejadian DBD pada anak. Pemakaian pakaian panjang merupakan salah satu upaya mencegah gigitan nyamuk. dan meminimalkan potensi gigitan nyamuk Aedes aegyti, karena pakaian panjang menutupi anggota badan, seperti tangan dan kaki. Hasil wawancara responden mengatakan bahwa dalam sehari-hari anak tidak selalu memakai pakaian panjang di rumah ataupun di sekolah.

Pemahaman bahwa penyakit DBD dapat dicegah dengan pemakaian pakaian panjang, maka orang tua dengan penuh kesadaran akan membiasakan anak-anak mereka untuk selalu memakai pakaian panjang baik di rumah maupun di sekolah. Hasil penelitian kualitatif yang dilakukan oleh Suwanbamrung, dkk pada sekolah dasar di Thailand, juga menyatakan bahwa dalam mencegah gigitan nyamuk, dapat menggunakan pakaian dan celana panjang serta menggunakan kelambu ketika tidur dan penelitian di Laos, mengungkapkan anjuran bagi pekerja di bidang perhutanan untuk memakai baju lengan panjang, celana panjang dan sepatu yang tertutup sebagai bentuk perlindungan diri terhadap gigitan nyamuk. ${ }^{20}$

Hasil ini sejalan dengan penelitian yang dilakukan oleh Muchlis, dkk yang menunjukkan bahwa OR $=2,208 ; 95 \%$ CI $=0,705-6,921$ yang berarti bahwa penggunaan pakaian panjang merupakan faktor risiko rendah terhadap kejadian DBD. ${ }^{21}$ Penelitian ini sejalan dengan hasil penelitian Mada dengan $p$-value 0,003 dan nilai $\mathrm{OR}=2,781 .{ }^{12}$ Hasil dari wawancara kepada responden tentang kebiasaan anak tidak memakai pakaian panjang responden menyatakan bahwa Responden Ny.A “....pake pakaian panjang ya kadangkadang ndak mesti, klo sekolah anak saya ya memakai pakaian panjang mba, klo sudah pulang sekolah di rumah ya pakai baju biasa tidak mesti panjang, sumuk to ya mba..koyoe gerah."

Responden Ny.N

“......anak saya ngga suka pakai pakaian panjang, kurang enak kalo untuk aktifitas bermain, jadi lebih suka pakai kaos oblong dan celana pendek klo disekolah kan tidak pakai baju panjang juga karena sekolahnya diyayasan nonmuslim...." 


\section{Kebiasaan memakai obat anti nyamuk}

Hasil penelitian ini menunjukkan bahwa uji statistik diperoleh nilai $p$ value 0,001 yang berarti ada pengaruh faktor penggunaan obat anti nyamuk terhadap kejadian DBD pada anak. Sejalan dengan penelitian yang dilakukan Ishak bahwa penggunaan obat anti nyamuk merupakan faktor risiko tinggi untuk menghindari gigitan nyamuk. $^{21}$

Temuan di lapangan sebagian responden tidak pernah menggunakan anti nyamuk pada siang hari, tetapi sebaliknya menggunakan anti nyamuk seperti menyemprot atau menggunakan kelambu hanya pada malam hari saja, anggapan mereka bahwa pada siang hari lebih banyak beraktifitas sehingga perlindungan terhadap gigitan nyamuk tidak perlu dilakukan. Sejalan dengan hasil penelitian Ayun di puskesmas Sekaran menyatakan kebiasaan memakai lotion anti nyamuk secara statistik berpengaruh dengan kejadian $\mathrm{DBD} \quad \mathrm{OR}=4,200 ; \mathrm{p}=0,042 .{ }^{22}$ Berbeda dengan hasil penelitian Endo di Kecamatan Purwokerto Timur diperoleh nilai $p$ value 0,072 bahwa tidak ada hubungan antara kebiasaan menggunakan obat anti nyamuk dengan kejadian DBD. ${ }^{(23)}$

Penelitian ini sejalan dengan hasil penelitian yang dilakukan oleh Sitio yang menunjukkan hasil bahwa penggunaan anti nyamuk berhubungan dengan kejadian DBD $\quad(\mathrm{OR}=4,343 ; p=0,026) .{ }^{24}$ Menurut WHO penolak serangga merupakan sarana perlindungan diri terhadap nyamuk dan serangga yang umum digunakan. Benda ini secara garis besarnya dibagi menjadi dua kategori, penolak alami dan kimiawi. Hal ini sesuai dengan teori Hendrawan Nadesul bahwa cara lain untuk menghindari gigitan nyamuk adalah dengan membaluri kulit badan dengan obat anti nyamuk (repellent). ${ }^{22}$

\section{Kesimpulan}

Faktor yang terbukti berpengaruh terhadap kejadian DBD pada anak usia 612 tahun yaitu pendidikan ibu rendah, kebiasaan tidak memakai obat anti nyamuk dan kebiasaan tidak memakai pakaian panjang. Probabilitas untuk terjadinya DBD jika terdapat 3 faktor risiko tersebut secara bersamaan adalah $85,3 \%$, faktor yang terbukti tidak berpengaruh: kebiasaan tidur siang, kebiasaan menggantung pakaian, forum penyampaian informasi dan rutinitas pemeriksaan jentik dan praktik PSN.

\section{Ucapan Terimakasih}

Terimakasih kepada masyarakat di Kecamatan Tembalang yang bersedia menjadi obyek penelitian dan memberikan kontribusi dalam pengumpulan data.

\section{Daftar Pustaka}

1. Halstead SB. 2008. Dengue. Tropical Medicine Science and Practice. Imeperial college press; volume 5.

2. WHO. 2016. Dengue Situation Update 498. Geneva WHO west pasific reg.

3. WHO. 2014. Estimates of The Global Burden of Diseases. WHO;46(3).pp.1-15.

4. Kementrian Kesehatan. 2017. Profil Data Kesehatan Indonesia Tahun 2016 [Internet]. Jakarta: Kementerian Kesehatan RI.pp.507.

5. Kementerian Kesehatan RI. 2016. Profil Kesehatan Indonesia.pp.1-220.

6. Dinas Kesehatan Provinsi Jawa Tengah. 2017. Buku saku kesehatan Triwulan 3 [Internet].pp.30-36.

7. Dinkes Kota Semarang. 2016. Profil Kesehatan Kota Semarang 2016. [Internet].pp.72. Available from: http://www.dinkes.semarangkota.go.id 
/hews

8. Dinas Kesehatan Semarang. 2015. Profil Kesehatan Kota Semarang 2015.

9. Pujiyanti A, Pratamawati DA. 2014. Pengendalian Vektor Demam Berdarah Dengue Pada Komunitas Sekolah Dasar di Kecamatan Tembalang, Kota Semarang. Vektora ; 6(2).pp.46-51.

10. Kementrian Kesehatan RI. 2011. Modul Pengendalian Demam Berdarah Dengue. Jakarta: Direktorat PP dan PL.

11. Sari P, Martini, Ginanjar P. 2012. Hubungan Kepadatan Jentik Aedes sp dan Praktik PSN dengan Kejadian DBD di Sekolah Tingkat Dasar di Kota Semarang. Jurnal Kesehatan Masyarakat;1.pp.413-422.

12. Soebowo MG, Prasetya DI, Hadisaputro S, Adi S. 2017. Pengaruh Seragamisasi Celana/Rok Panjang Dalam Mencegah Kejadian DBD pada Siswa Sekolah Dasar. pp.163-172.

13. Puskesmas Kedungmundu.2017. Data Surveilans Penyakit Menular. Lap Penyakit.

14. Puskesmas Rowosari. 2017. Data Surveilans Puskesmas. Lap Penyakit.

15. Notoatmodjo S. 2010. Metodologi Penelitian Kesehatan. Jakarta : Rineka Cipta.

16. Kemenkes RI. 2013. Pengendalian demam berdarah dengue untuk pengelola Program DBD Puskesmas. Jakarta: Dirjen P2P.

17. Notoatmodjo S. 2013. Promosi Kesehatan dan Ilmu Perilaku. Jakarta : PT Rineka Cipta.

18. Fathi, Keman S, Wahyuni CU. 2005. Peran Faktor Lingkungan dan Perilaku Terhadap Penularan Demam Berdarah Dengue di Kota Mataram. Jurnal Kesehatan Lingkungan;2(1).pp.1-10.

19. Widiyanto T. 2007. Kajian Manajemen Lingkungan Terhadap Kejadian
Demam Berdarah Dengue di Kota Purwokerto Jawa-Tengah. [Tesis] Magister Kesehat Lingkung Univ Diponegoro.pp.126.

20. Tangena JA, Thammavong, Lindsay.2017. Risk of Exposure to Potential Vector Mosquitoes for Rural Workers in Northern Lao Pdr. PloS Negl Trop Dis;11(7).pp.1-17.

21. Muchlis, S., Ishak, H., \& Ibrahim E.2014. Faktor Risiko Upaya Menghindari Gigitan Nyamuk Terhadap Kejadian DBD di Puskesmas Pattiloang Makassar. repository.unhas [Internet];4. Available from: repository.unhas.ac.id

22. Ayun LL, Pawenang ET. 2017. Hubungan antara faktor Lingkungan Fisik dan Perilaku dengan kejadian Demam Berdarah Dengue di Wilayah Kerja Puskesmas Sekaran, Kecamatan Gunungpati , Kota Semarang. Public Health Perspective Jurnal;2(1).pp.97104.

23. Dardjito E, Yuniarno S, Wibowo C, Dwiyanti H, Achmad MH, Utara J. 2008. Beberapa Faktor Risiko yang Berpengaruh Terhadap Kejadian Penyakit Demam Berdarah Dengue (DBD) di Kabupaten Banyumas; XVIII.pp.126-136.

24. Sitio A. 2008. Hubungan Perilaku tentang PSN dan Kebiasaan Keluarga dengan Kejadian DBD di Kecamatam Medan Perjuangan Kota Medan Tahun 2008. TESIS Univ Diponegoro Semarang [Internet].pp.20-23.

25. Abbas A, Syafar M, Arsin AA. 2010. Faktor yang Berhubungan dengan Kejadian DBD di Kabupaten Jeneponto;6(2).

26. Jata D, Putra NA, Pujaastawa IBG. 2016.Hubungan Perilaku Masyarakat dalam Pemberantasan Sarang Nyamuk dan Faktor Lingkungan Dengan Kejadian DBD di Wilayah Puskesmas I Denpasar Selatan Dan Puskesmas I 
Denpasar Timur. Ecotrophic;10(1).pp. $17-21$.

27. Lumingas ER, Kaunang W.P.J, Asrifuddin A. 2017.Faktor-faktor yang Berhubungan dengan Kejadian Demam Berdarah Dengue di Wilayah Kerja Puskesmas Tanawangko. Media Kesehat [Internet];9. Available from: ejournalhealth.com/index.php/medkes /article/view/336
28. Rosidi AR, Adisasmito W. 2009. Hubungan Faktor Penggerakan PSN Demam Berdarah Dengue dengan Angka Bebas Jentik di Kecamatan Sumberjaya Kabupaten Majalengka, Jawa Barat. Majalah Kedokteran Bandung;41(2).pp.1-7. 